\title{
THE RIVERINE FLOOD CATASTROPHE IN AUGUST 2010 IN SOUTH PUNJAB, PAKISTAN: POTENTIAL CAUSES, EXTENT AND DAMAGE ASSESSMENT
}

\author{
SAJJAD, A. ${ }^{1}-$ LU, J. Z. $.^{*}-$ CHEN, X. L. ${ }^{1}-$ CHISENGA, C. ${ }^{1}-$ MAHMOOD, S. ${ }^{2}$ \\ ${ }^{1}$ State Key Laboratory of Information Engineering in Surveying, Mapping and Remote Sensing, \\ Wuhan University, Wuhan 430079, China \\ ${ }^{2}$ Department of Geography, Government College University, Lahore, Pakistan \\ *Corresponding author \\ email: lujzhong@whu.edu.cn; phone: +86-27-6877-8755
}

(Received 29 $9^{\text {th }}$ May 2019; accepted $16^{\text {th }}$ Oct 2019)

\begin{abstract}
The paper investigates the causes, magnitude and damage caused by the flood as a result of the breaching of the east marginal embankment of the Taunsa Barrage. The flood frequency in the district of Muzaffar Garh located in south Punjab, Pakistan had serious impacts on human lives and their properties. To pursue this study, we used primary data, collected through questionnaire, formal interviews, field observations and secondary data, obtained through government departments and online open source databases. Furthermore, Landsat ETM+ imageries were used as input in the supervised classification in order to investigate the pre and post flooding land cover and land use. Hydrograph was used to analyze the flood limits and spatiotemporal change in river discharge for barrages. The results show an abnormal rainfall occurring in the month of July in the upper Indus Basin, which resulted in a massive discharge in the central Indus Basin. As a consequence, it exceeded the flood limits at the Taunsa Barrage, which resulted in the breaching of east marginal embankment. The flood caused a high number of human casualties and a total economic loss of 14.23 million US\$ including a 6.8 million US\$ agricultural loss. The study thus, gives insight on how authorities can devise a flood management plan in such a way to reduce the future impacts of riverine flood disasters in Muzaffar garh.
\end{abstract}

Keywords: Indus Basin, east marginal embankment, flood disaster management, supervised classification, abnormal rainfall

\section{Introduction}

Floods are the most frequent and destructive hydrological disasters in the world (Banerjee, 2010; Cann et al., 2013). In recent years, the severity and magnitude of excessive flooding has been experienced by many South Asian countries, including Pakistan, India and Bangladesh (Khan et al., 2009), which caused devastation to greater number of people as compared to other nature hazards(Zhou et al., 2000; Khan et al., 2009; Haq et al., 2012). Generally, floods have been widely caused by certain factors including unpreceded rainfall, melting of ice and snow, breaching of river embankment, improper structural measures and insufficient capacity of reservoirs (Howe and White, 2002; Shah and Gabriel, 2002; Ali, 2013). Similarly, population growth, land use change, deforestation, degradation of ecosystems, human encroachments in floodplains are some of the human escalation factors (Milly et al., 2002). Over the last few decades, the frequency and intensity of riverine flooding have been immensely boosted by various factors, including unusual climatic variability, abrupt sea level rise and extreme rainfall (Tariq and Giesen, 2012; Rehman and Khan, 2013; Dawood et al., 2017). In recent years, a large number of riverine floods have been triggered by the failure of dams, barrages and embankments, which rendered disastrous capacity to disrupt human 
life and their property due to unpredictability and severity (Walder and O'connor, 1997). Moreover, riverine floods in the Indus Basin are induced by various factors, including flat topography, hydrology, climate, demographic and socio-economic catchment characteristic in the proximity of Indus river (Gaurav et al., 2011; Tariq and Giesen, 2012; Laghari et al., 2012). Riverine flooding is extremely destructive in terms of life loss with shattering economic developments to all sectors (Zhou et al., 2000).

Globally, floods produce severe damages to all socio-economic sectors. Every year, flood events have directly claim more than 20,000 lives and affect 1.4 million people (Howe and White, 2002; Messner et al., 2007). Categorically, management of flooding impacts involve three stages: the first stage is the estimation of flood inundation extent, the second stage is the estimation of damage to all socio-economic sectors and the last stage is flood recovery and rehabilitation (Zhou et al., 2000; Shah and Gabriel, 2002). These following marked flood impacts can be tackled down by applying certain structural and non-structural strategies (Rehman and Khan, 2011; Gaurav et al., 2011; Tariq and Giesen, 2012).

In Pakistan, flood is a frequent hydrological hazard (Khan, 2005; Syvitski and Brakenridge, 2013; Mahmood and Rani, 2018; Mahmood et al., 2019). Pakistan is considered as the most flood affected country in the world (Solheim et al., 2001; Natalia et al., 2008). In the last few decades, number of shattering floods of various magnitudes have recurrently been influenced by topographical and geological characteristics and climate change (Gaurav et al., 2011; Geis and Steeves, 1998). In addition, some human escalation factors have worsened the situation, which included urbanization, population growth in the proximity of floodplain, deforestation and ill equipped flood managers (Laghari et al., 2012; Khan, 2005; Ghosh et al., 2015). These factors have increased the risk of flooding in Pakistan and also increased the danger of loss of lives, damages to the infrastructure, standing agriculture crops and other vital properties (FFC, 2010; Hashmi et al., 2012). In this regard, an appropriate structural modifications and nonstructural measures are required to efficiently cope with this menace (Khan et al., 2009).

In 2010, Pakistan was hit by the worst flood in the history of the Indo-Pak subcontinent, which was caused by widespread heavy rain spell of more than $250 \mathrm{~mm}$. The rainfall occurred from the 27th to the 31st July with much intense in the catchment area of the upper Indus Basin (Rahman and Khan, 2011, 2013). As a consequence, flash flooding occurred in the upper Indus Basin and riverine flooding has occurred in the central Indus Basin. Over 2000 death tolls and massive acceleration in economic loss of 43 billion US\$ was recorded (PMD, 2010; Rahman and Khan, 2013 Mahmood et al., 2016a, b, 2019). Previous studies have studied the magnitude and intensity of flood damages, as a result of fluvial geomorphology, population density, land use change, structural river embankments, levees and irrigation systems (Syvitski and Brakenridge, 2013; Mahmood et al., 2016a, b). Nevertheless, the destructive effect in the whole Indus Basin was due to breaching of embankments, floodplains coupled with high population density, and economic growth (Ali, 2013; Chaudary and Sarwar, 2016; Mahmood et al., 2019). Furthermore, the flood's high peak runoff of $31149 \mathrm{~m}^{3} / \mathrm{s}$, exceeds the flood limits of various barrages and dams along the River Indus, including the Taunsa Barrage that falls within our study area (FFC, 2010; Chaudary and Sarwar, 2014, 2016; Mahmood et al., 2019).

Since 2010, a number of studies have been conducted to understand the causes and effects of flooding (e.g., Rahman and Khan, 2011, 2013; Syvitski and Brakenridge, 2013; Hashmi et al., 2012; Mahmood et al., 2016a, b, 2019; Khalid et al., 2018). 
However, these studies focused on the upper section of the River Indus with little or no emphasis on the middle section and the contribution caused by a number of series of barrages. The middle section of the river is of paramount importance as it has unique characteristics, one of which is the contribution to flooding pattern as the result of the Taunsa Barrage breach. Thus, this study focused on integrating the effect of the Taunsa Barrage and remote sensing results to better understand the causes, effects and damages caused by the flood in 2010. Remote sensing provides a framework to flood monitoring, depicts fluvial morphological changes, and extracts flood inundation and damages (Haq et al., 2012; El Bastawesy, 2015). We used supervised classification techniques, coupled with multispectral and temporal remote sensing data, to map the flood extent, damages to infrastructure and changes in river courses (e.g., Khalid et al., 2018). The land use and land cover change analysis of pre and post flooding in Muzaffar garh and in downstream areas of the Taunsa Barrage, which have not been done before, thus providing useful information for the implementation of flood protection measures along study area. We then explored the prevailing effects of the monsoon rainfall and the huge discharge over Upstream Indus Basin and the breaching of Taunsa Barrage. Thus, the present study provides a flood management plan framework to authorities on the management of future flood in relation to the control of Barrages and other flood barriers. This framework incorporates the flood generating factors and associated damages, the flood extent in relation to the land use/cover changed as the result of the flood in 2010, the water Inflow of the Taunsa and Chashma barrages to address how future managements of these barrages will reduce the effect of floods. The main objective of this present study is assessing the 2010 flood-causing factors, extent of inundation and associated socio-economic damages in one of the severely floodaffected areas in the south Punjab district Muzaffar garh, Pakistan. Further the study is focusing on filling the afore knowledge gap and introducing the use of combined techniques in Geographical Information System and climate data analysis as a monitoring tool in flood risk management in the future.

\section{Materials and methods}

\section{Study area}

The district Muzaffar garh is located in south Punjab, central Pakistan within $29.016^{\circ} \mathrm{N}$ to $30.765^{\circ} \mathrm{N}$ and $70.537^{\circ} \mathrm{E}$ to $71.726^{\circ} \mathrm{E}$ (Fig. 1). It is $\sim 34 \mathrm{~km}$ away from Multan, which is regarding its population the 5th largest historical city of south Punjab, Pakistan. It is bounded by Layyah and Jhang districts in the north and Rahimyar Khan and Bahawalpur along River Chenab in the south. Dera Ghazi Khan and Rajaun pur along the mighty Indus are located in the west while Multan and Khanewal district lie in the East. Geographically, it is sandwiched between the mighty Indus and Chenab Rivers in the western and eastern borders, approximately $35 \mathrm{~km}$ and $8 \mathrm{~km}$ from district headquarter, respectively (Fig. 1). The total geographical area is $8,250 \mathrm{~km}^{2}$, which is administratively divided into four tehsils; Muzaffar garh, Kot addu, Alipur, and Jatoi. Furthermore, it is subdivided into 93 smallest electoral units (Union Councils). In accordance with the latest 2017 census, the total population of the district was 4.32 million with $84 \%$ in rural areas and $16 \%$ urban population in comparison with the 1998 census with a total population of 2.64 million in 1998 with $88 \%$ rural and $12 \%$ urban population. The recorded average annual growth rate is 2.63 from 1998 to 2017 (Gop, 1999, 2017). 
Elevation varies from $42 \mathrm{~m}$ to $192 \mathrm{~m}$ above mean sea level from south to north, respectively (Fig. 8). The natural gradual slope in the district is toward the south, which made it possible to build an extensive irrigation canal system (Gop, 1999, 2017). District Muzaffar garh has desert type of climate, which is further classified as BWh, according to Koppen climate model (Mahmood et al., 2019). The highest maximum recorded temperature is $50{ }^{\circ} \mathrm{C}$ in the hottest month of June and the lowest is $2{ }^{\circ} \mathrm{C}$ recorded in the coldest month of January (PMD, 2010). The annual mean rainfall is $157 \mathrm{~mm}$ with a maximum of $45 \mathrm{~mm}$ monsoon rainfall in July a minimum of only $2 \mathrm{~mm}$ rainfall in October (PMD, 2010) The soil is fertile with the properties of sandy loam, which is suitable for widespread range of crops. In the study area, around 1,020,000 ha $(60 \%)$ of land is characterized as barren land, which is not suitable for cultivation. The remaining 680,000 ha $(40 \%)$ of land is cultivated with wide variety of crops including wheat, rice, sugarcane (Gop, 1999, 2017).

This paper emphasized the use of mixed research method approach to understand the flood causes, extent and evaluate the flood damages in the study area. To obtain the required objectives, primary and secondary data sources were used.

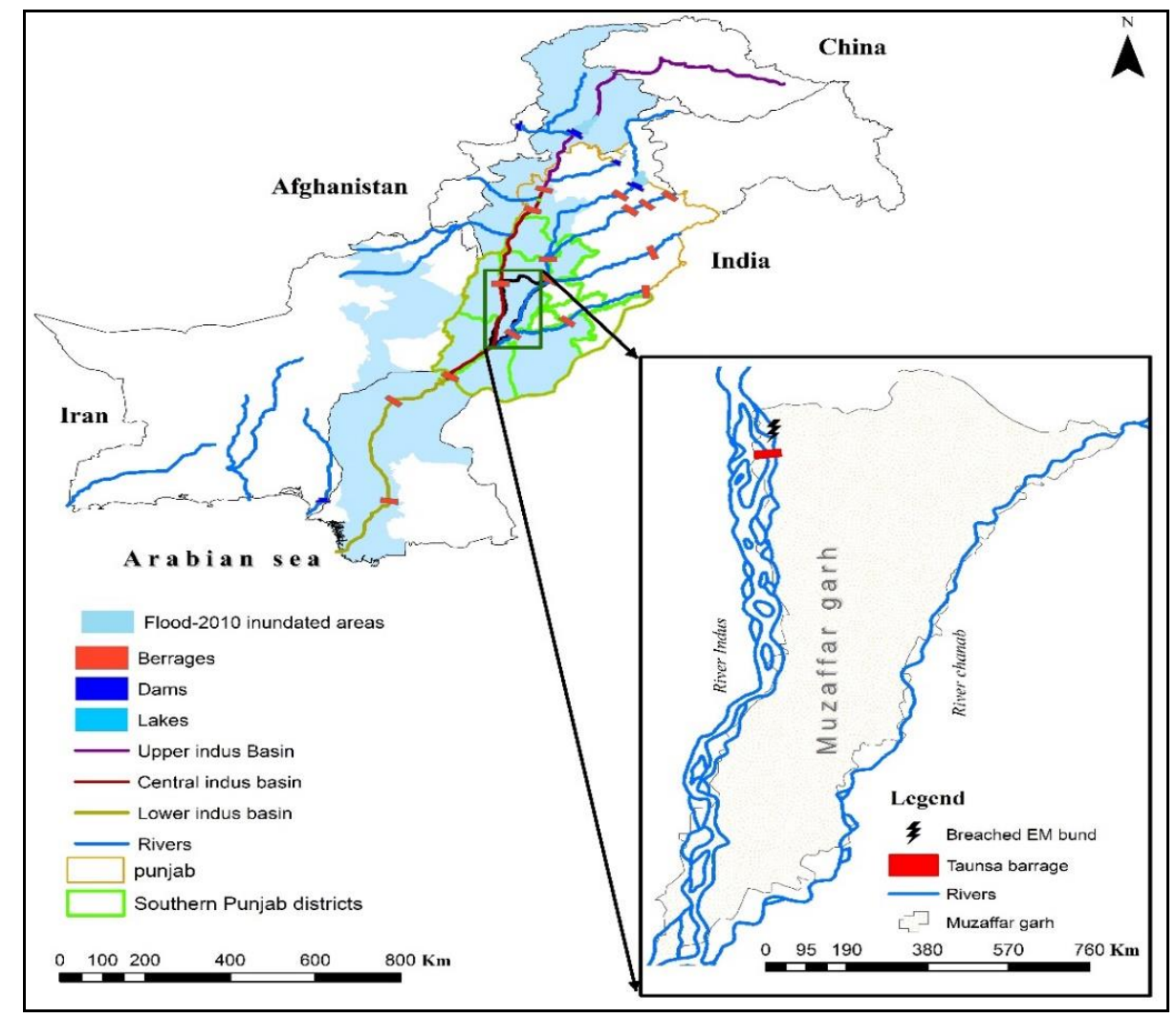

Figure 1. Pakistan location of study area

\section{Primary data acquisition}

Primary data was acquired through questionnaire-based survey, formal interviews and personal field observation and GPS. Prior to the survey, some frequent spatial field visits were conducted along with certain meetings arranged with different stakeholders, i.e. local communities, local irrigation department officials and farmers. The aim was to identify the most affected areas for conducting field survey. Based on prior field visits, 
comprehensive micro-level flood investigation and damage analysis of flood affected communities were examined. For this purpose, a semi-structured questionnaire was designed for the surveyed households to assess the flood genesis, magnitude and flood damages from three aspects. The first questionnaire was dealing with socio-economic condition of the household's while the second questionnaire was comprised of questions concerning flood causes, magnitude and damages to agricultural crops, livestock's, and houses with estimate loss in US\$. Likewise, questionnaire for formal interviews with concerned government officials was designed to get the information of flood causes and damages and estimated rehabilitation cost of flood affected areas in million US\$. A total of 500 households were selected on the basis of simple random technique. In the year of 2012, field survey was conducted by asking face to face afore mentioned questions in local language 'Saraiki'. Similarly, Global Positioning System (GPS) has been used to collect a total of 100 flood depth points in the study area, and sample training points of supervised classification classes e.g. water, built up, vegetation and barren land were examined to validate the result. On the other hand, the surveyed household locations were also taken along with infrastructure damages, and site locations were also noted. Field observation was also carried out in the study area to estimate flood extent, duration and depth. Similarly, correlation of flood duration and depth with Extent of damages to standing crops, livestock, housing structures were comprehensively investigated. Furthermore, identification of the most affected sites and the most vulnerable areas to flood in the study area were defined. Formal interviews were arranged with officials of government departments at provincial and district levels to get real time information of flood causes and estimated economic losses to all socioeconomic sectors in US\$.

\section{Secondary data acquisition}

Secondary data was acquired from different concerned government departments of Pakistan, and online open sources databases. In fact, there is no one single operating department to deal comprehensively with flood hazards in Pakistan. Further, flood hazard responsibilities are shared by various government departments. Topographic map of district Muzaffar garh was acquired from the Survey of Pakistan (SOP), Islamabad. Meteorological Rainfall data of 14 stations during 2010 were collected from the Pakistan Meteorology Department (PMD), Regional Office Lahore (PMD, 2010). Demographic statistics of Muzaffar garh district were acquired from the Population Census Organization, Islamabad (Gop, 2017). Economic loss to public roads infrastructures were collected from the Communication and Work Department, Muzaffar garh. Economic damages to electric power lines was collected from the Multan Electric Power Company (MEPCO) and river discharge data were collected from the Water and Power Development Authority (WAPDA), Pakistan.

Remote sensing Landsat 7 Enhanced Thematic mapper (ETM) images were downloaded from the United State Geological Survey (USGS) Landsat archive (https://earthexplorer.usgs.gov/). It was used to monitor pre and post-flood-2010 activities along the central Indus Basin, in district Muzaffar garh, south Punjab. Due to access of extensive spatio-temporal satellite imageries, it was easy to monitor flood extent and assess flood damages. Landsat ETM Image of 03 July, 2010 was used for pre-flood instance while ETM image of 20 August, 2010 was used for post-flood analysis. The effective spatial resolution and spectral sensitivity of Landsat ETM in visible and near infrared portion of electromagnetic spectrum have been useful for the 
extraction of flood inundation, flood damage assessment and monitoring (Chohan et al., 2015; Khalid et al., 2018). Shuttle Radar Topography Mission (SRTM) Digital Elevation Model (DEM) with $30 \mathrm{~m}$ resolution was downloaded from USGS open access archive. We have used for an understanding the spatial variations in the elevation in Muzaffar garh district.

Google Earth images of pre-flood 2009 and post-flood 2011 were acquired from Google earth Pro, which were used for observing the breaching points and their reconstruction.

\section{Data methods and preparation}

We used supervised classifications to separate different land cover and land use on the Landsat ETM images. The supervised image classification is widely used for the extraction of detailed invisible information from remote sensing data (Melgani and Bruzzone, 2004). It is a well-known automation technique that converts pixels into land use/cover change detection at a same location (Alphan et al., 2009). Maximum likelihood approach of supervised image classification was used for the mapping of preand post-flooding occasions in the study area. This technique has also been applied in a similar study by Khalid et al. (2018) and Chohan et al. (2015). Four classes were identified namely, water, built up, vegetation and barren land in the study area. Maximum likelihood approach is widely applied by various studies due to its results reliability and accuracy compared to other approaches. It provides a quantitative decision in which pixels are assigned based on their likelihood spectral signature classes by using sample training points (e.g. Chohan et al., 2015; Khalid et al., 2018). Global positioning system was also used to collect sample training points for the validation of spectral signatures of land use/cover classes (Table 1).

Table 1. Training sites for image classification

\begin{tabular}{c|c|c|c}
\hline Sr. No & Class type & Latitude & Longitude \\
\hline 1 & Water & 30.5161 & 70.8486 \\
2 & Built up & 30.4899 & 70.9386 \\
3 & Vegetation & 30.3946 & 70.8997 \\
4 & Barren land & 30.3747 & 71.3077 \\
\hline
\end{tabular}

Moreover, we used change detection method, based on the classified classes for the pre and post flood images, to investigate the significant land use and land cover changes due to flooding phenomena in the study area. We have applied this change detection method on both images using Raster calculator tool in GIS environment. After that supervised classification of both pre and post images were presented in a map and change statistics results were compiled and presented in graphical form using MS Excel.

Meteorological rainfall data was collected from 14 meteorological stations located in all provinces of Pakistan from 27-31 July, 2010. Geo-database was prepared to store, manipulate, and geo-visualize spatiotemporal rainfall data in GIS environment. Moreover, Rainfall spatial distribution pattern was analyzed and interpolated using Inverse distance weightage (IDW) spatial analysis tool in Arc GIS. This technique (IDW) is ideal to interpolate scattered points, which employ deterministic methods to calculate the values of unknown points using weighed averages (Rehman and Khan, 2011, 2013). In this approach, it assumes that close points are related to each other that 
diminish with distance, hence the inverse distance weighing. Similarly, this IDW technique was also applied to interpolate flood depth in the study area to geo-visualize the spatial pattern of flood depth.

Digital elevation model data files contain spatial terrain altitude at a defined grid interval over the bare Earth. ArcGIS 10.4.1 was used to analyze the spatial variance in terrain elevation in the study area.

Descriptive statistical analysis was applied on the collected socio-economic data and, and flood damages data using MS Excel. Arithmetic mean formula was applied to determine the average estimated economic loss of agriculture crops per ha. The estimated loss to all sectors were calculated in US\$ and presented in graphical and tabular form. River Indus discharge data of Chashma and Taunsa stations from 29 July to 06 August, 2010 was collected from the Water and power development authority. Discharge data was prepared and organised in MS excel and presented in a hydrograph. Hydrograph is an ideal method to present any timeline series data. Additionally, the rainfall trends during monsoon rainfall from the years of 2001-2010 were also analyzed, compared and presented in line graph method.

\section{Results and analysis}

\section{Socio-economic characteristics}

A total of 500 households were surveyed from Kot addu, Muzaffar garh, Ali pur and Jatoi with a total population of 1617 persons. Out of which 915 were male and 702 were females. A total of $36.6 \%$ households were from Kot addu, $14 \%$ households were from Muzzafar garh, while $16.4 \%$ and $33 \%$ households were from Jatoi and Ali pur, respectively. The age structure of the respondents was classified into three main age groups; the 1st group (20-40 years) was $37.8 \%$ of total respondents, the 2nd group (4160 years) was $54.2 \%$ and the 3rd group (46-60 years) made $8 \%$ of the total households. The family size was divided into four categories; Small family size of less than 4 members was $62 \%$, medium size consist of 4 to 8 members was $28 \%$ and large family size of above 8 members made $10 \%$ of the total surveyed population. The flood in 2010 has induced direct implications on the well-being of these households. It damaged their limited assets and sources of earning, which consequently push them into extreme poverty level. The survey indicated that literacy ratio is $83 \%$ in the study area. Most of them were only literate at matric level and only few of them were at graduate and postgraduate level. The survey indicated that more than $60 \%$ respondents belong to daily wagers profession with less than 130 US\$ earnings monthly.

\section{Perceived causes of flood-2010}

The 2010 flood in the central Indus Basin in south Punjab started in early August and continued till early September, following heavy prolong rainfall in the upstream of the Indus. Spatial Analysis of the rainfall data from 27-31 July was published by the Pakistan Metrological Department, which had experienced much higher rainfall in many stations in the monsoon season in 2010 in Khyber Pakhtunkhwa (KPK), Punjab, and Sindh provinces as shown in Figure 2. For example, abnormal heavy rainfall over 250 $\mathrm{mm}$ in $24 \mathrm{~h}$ had been recorded at Saidu sharif station located in KPK province. Similarly, northwestern part of the country had received high concentration of rainfall in 
comparison with the central and southern part of the country, which had received very low rainfall as depicted by rainfall spatial pattern analysis (Fig. 2).

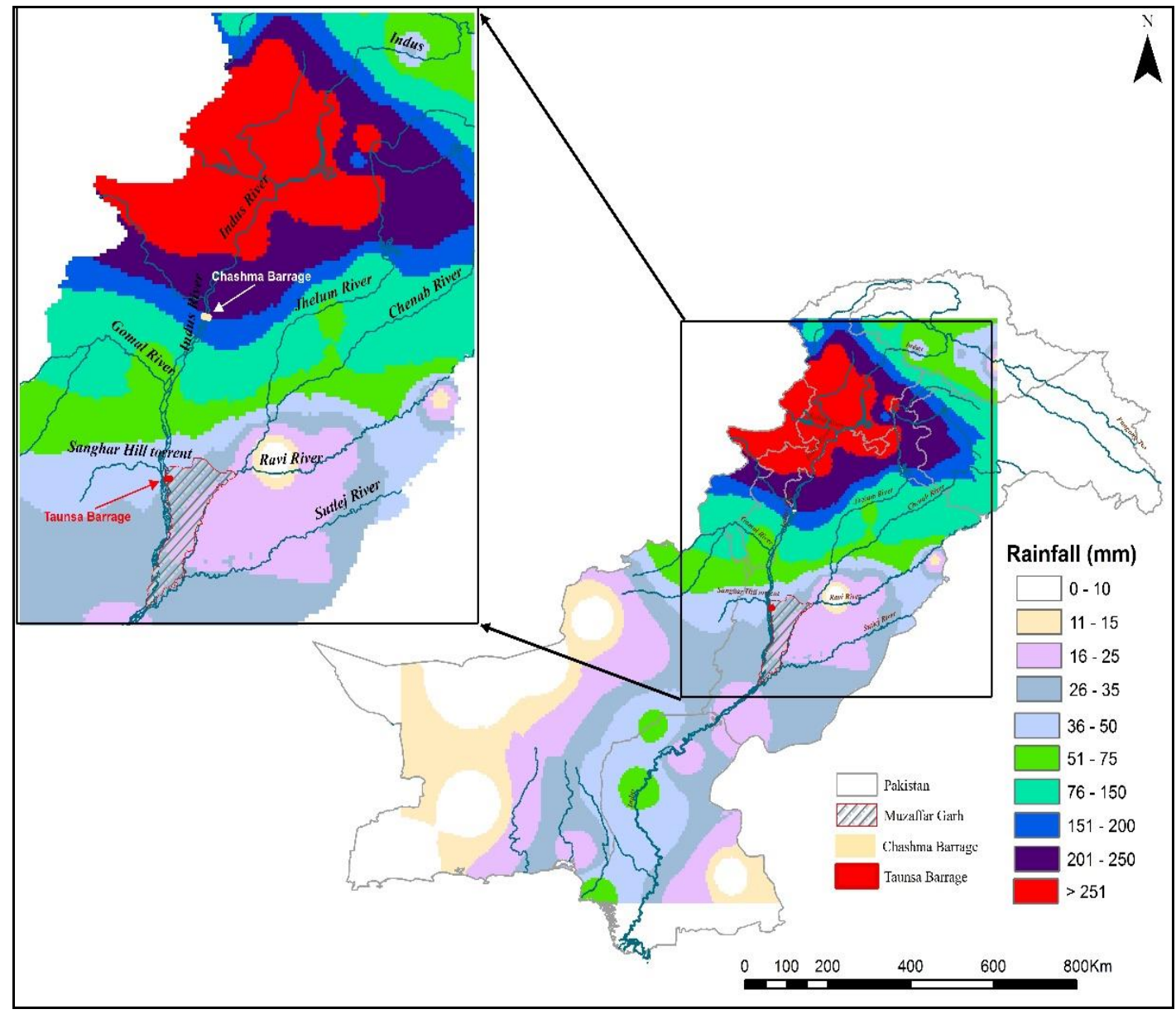

Figure 2. Spatial pattern of rainfall from 27-30 July, 2010

As a result of high intensity and continuous downpour in the upstream of the Indus river carried very high surface run off discharge and abnormal flow at several western tributaries of the Indus namely, Swat, Dir, Kabul, Panjkore, Gomal rivers, which caused an adverse flash flooding in KPK province, Pakistan. The hydrological data analysis shows that the unprecedented accumulated flood water recorded discharge of 26546 $\mathrm{m}^{3} / \mathrm{s}$ on 30 July at Jinnah Barrage resulted in severe breaches at its left and right Guide Banks and inundated nearby low lying areas. Further, this extreme swollen water flow discharge generated high intense pressure at Chashma Barrage with an alarming level of recorded inflow $29354 \mathrm{~m}^{3} / \mathrm{s}$, and resulted inundation in the floodplain areas of districts Mianwali, Bhakhar and Layyah. The high flow of water with its disastrous consequences rushed down toward Taunsa Barrage and generated intense pressure on both sides of its embankments. Further, the recorded high flood peak of $27184 \mathrm{~m}^{3} / \mathrm{s}$ on 2 August, 2010 at Taunsa Barrage not just exceeded the discharges at danger levels but it was also very close to its designed capacity of $28317 \mathrm{~m}^{3} / \mathrm{s}$. This recorded inflow water piled at the barrage and resulting the pressure of the East bank and the protective embankment. As a result, $12 \mathrm{~km}$ upstream of Taunsa Barrage, the east marginal embankment (EM) Abbas wala could not sustain the tremendous pressure and breached 
at Rd 32-38 on the 2nd August with 1972 m length. Thereafter, three main secondary breaches of $140 \mathrm{~m}, 120 \mathrm{~m}$, and $448 \mathrm{~m}$ have been formed subsequently to adjacent embankment as a consequence of EM embankment breach (Fig. 6). The approximate disastrous flow of more than, $3540 \mathrm{~m}^{3} / \mathrm{s}$ roaring flood water through breached embankments, overtopped Taunsa Panjnad Link canal by breaching at Rd 10 and continued its disastrous flow followed by various breaches to Muzaffar garh canal in between Rd 13-14. As a result, the water gushing went on to flood the Muzaffargarh district and its adjoining areas. The hydrological analysis result shows the recorded 6 hourly discharge at Chashma-Taunsa barrages during flood instance that is closely matching with the breaching dates of the embankments (Fig. 3).

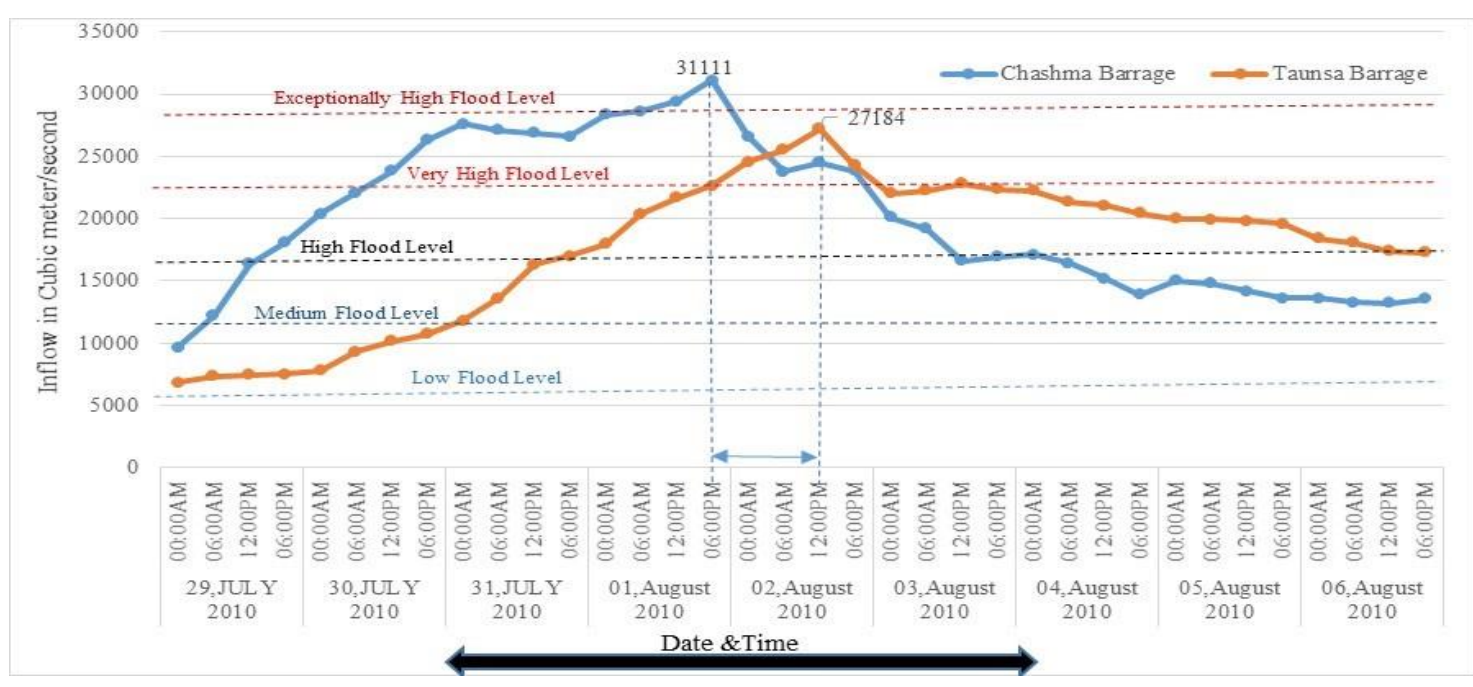

Figure 3. Inflow $\mathrm{m}^{3} / \mathrm{s}$ of Chashma Barrage and Taunsa Barrage from 29 July to 6 August 2010. Chashma-Taunsa reach is $\sim 270 \mathrm{~km}$

Over the last decade, the analysis revealed that the trend of monsoon rainfall in Pakistan was not uniform, in the year 2003 has received maximum rainfall, which was exceeded in 2010 with an exceptional rainfall above $250 \mathrm{~mm}$ as shown in Figure 4.

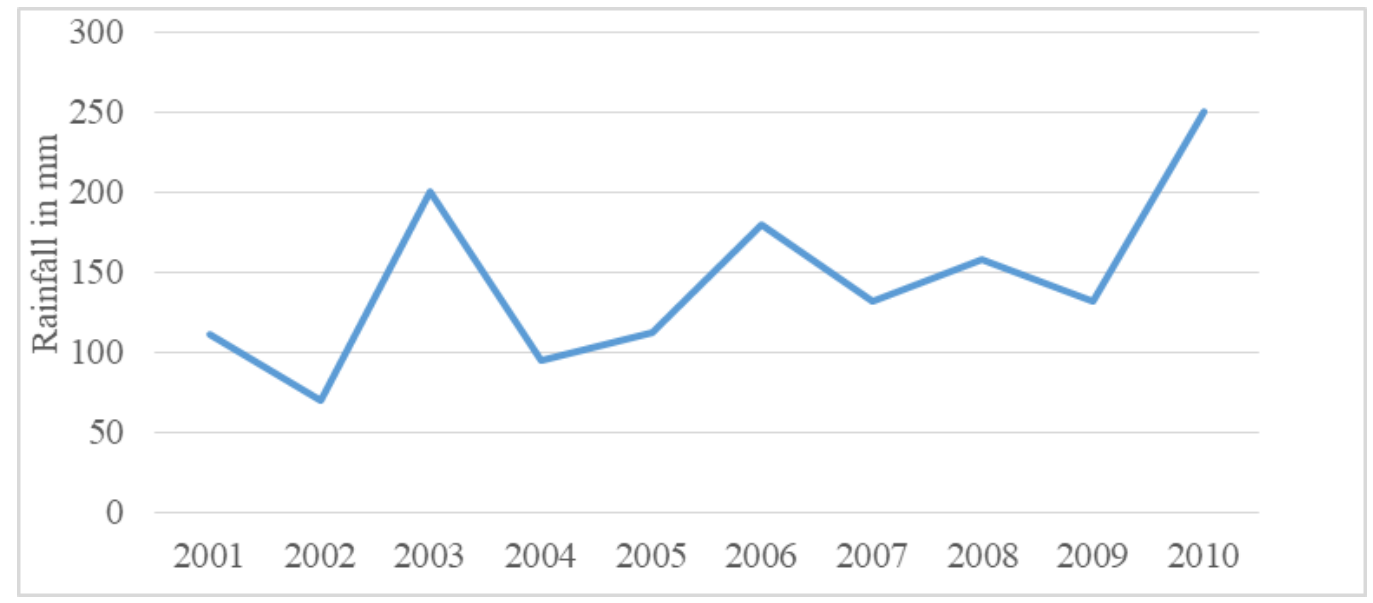

Figure 4. Monsoon rainfall trend in Pakistan from 2001-2010 
Taunsa Barrage is located in south Punjab district Muzaffar garh (Fig. 2). Taunsa Barrage is considered the most susceptible barrage structures built across the River Indus (Chaudary and Sarwar, 2016). As Figure 5 shows in the year 2008, for the purpose of diversion structure re-modelling the construction of a sub-weir was completed at Taunsa Barrage which had about $2.5 \mathrm{~m}$ vertical and $274 \mathrm{~m}$ horizontal length. For this construction work, a massive coffer dam was used. Consequently, after completing the construction work, the coffer dam discarded material remained at the top of sub weir caused a minor blockage at the downstream of the Taunsa Barrage (Chaudary and Sarwar, 2014). As a result, flood-2010 water level remained the same in the upstream and downstream of the barrage. Similarly, the rising riverbed resulted in the deposition of large amount of sediments downstream in head up area that has reduced the discharge capacity of the Taunsa Barrage and triggered the high waves of flood water back to its embankment on the eastern side and breached the protection EM embankment (Fig. 6).

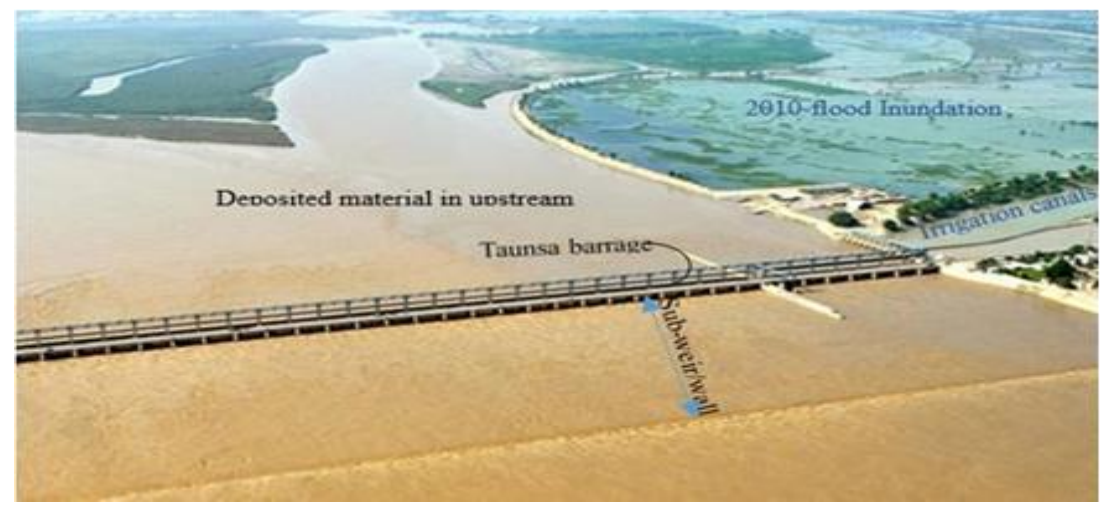

Figure 5. Aerial view of the Taunsa Barrage, construction of sub-weir, sediments in head up during the flood in 2010. (Source URL: https://www.dawn.com/news/1195398)

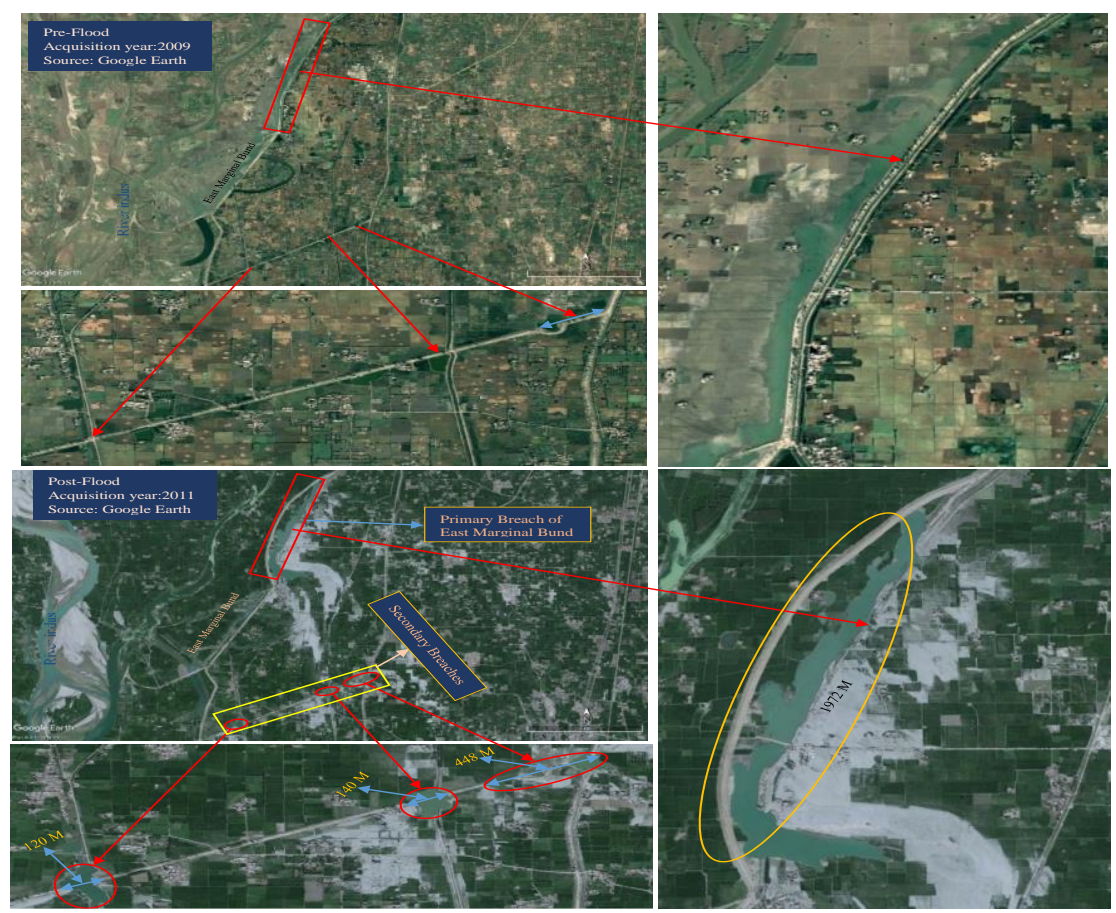

Figure 6. Pre and post flood images of breached East Marginal Embankment at Rd 32-38 
According to respondent perceptions regarding flood causing factors, 90\% had indicated that breaching of the EM embankment at Rd (32-38) Abbas Wala at the Taunsa Barrage had caused this flood menace in the study area. A total of $10 \%$ reported heavy monsoon rainfall in upstream areas of the Indus River. Based on indigenous knowledge of this phenomenon and previous experiences forest and irrigation officials described that deforestation along the canal embankment for fuel and timber purposes has weakened the canal banks along with unpaved canal, as a contributing factor of breaching of canal banks, waterlogging and floods in the rainy season in the study area.

\section{Extent of flood-2010}

The extent of flood-2010 analysis comprises of supervised classification of flooded areas and depth of inundated surveyed areas. The supervised classification was performed using Landsat ETM Images. The Landsat ETM image of the 3rd July, 2010 was classified for pre-flooding situation whereas image of the 20th August, 2010 was classified for postflood 2010 instance analysis. Further, we used change detection method, based on the classified classes for the pre and post flood images, to investigate the significance land use and land cover changes due to flooding phenomena as shown in Figure 7. The preflood image classification of the $3^{\text {rd }}$ July, 2010 shows that only $7 \%$ of the area was covered by water, while vegetation, built up and barren land were covered by $39.9 \%$, $30.03 \%$ and $22.8 \%$, respectively. Similarly, Post flood image classification of the $20^{\text {th }}$ August, shows that $24 \%$ of the area was covered by water while vegetation, built up and barren land were covered by $35 \%, 22 \%$ and $19 \%$, respectively. Both pre and post flood instances classifications show significant clear demarcation of defined classes. Post flood change detection analysis shows dramatic change in water class, with an increase from $7 \%$ to about $21 \%$ while built up area has decreased by $8.03 \%$, from $30.03 \%$ to $22 \%$ in post flood analysis. The vegetation decreased by $5 \%$, from $40 \%$ in pre-flood instance to $35 \%$ in post flood situation and the barren land decreased by $3.8 \%$ from an area of $22.8 \%$ in pre-flood instance to $19 \%$ recorded in post-flood situation (Fig. 7). Overall, the significant change was shown in water class in comparison with other classes and inundated an area of around $\sim 1732 \mathrm{~km}^{2}$ in the study areas. A total number of 1,780,226 people were affected in the 2010 flood (NDMA, 2010; PPDMA, 2010). The resulted inundation depth was found very uneven in the study area measured by GPS and measuring tape. The flood inundation depth was found very high in Kot addu area, due to high proximity to breached EM embankment as shown in Figure 1. Similarly, in Ali pur area, moderate flood inundation depth was found, as located in the lower reach of the study area where the Indus and Chenab rivers meet as shown in Figure 8. Comparatively, most of the socio-economic damages were reported from these areas.

\section{Damage assessment}

Analysis revealed that the flood in 2010 was severely disastrous and devastating in nature, however, it has caused serious damages at large scale to agriculture, human settlements and physical infrastructure in the study area. Flood damage assessment was done through Geo-spatial analysis and statistical analysis.

\section{Damage to agriculture}

The study area is one of the fertile floodplains of the Indus. Agriculture is the main source of economic activity, hence local residents are actively engaged in crop 
cultivations, in both Rabi and Kharif crop seasons. The analysis revealed that flood has badly affected the standing crops of Kharif season, including rice, sugarcane, cotton and fodder crop. A total of 4182.8 ha of agriculture standing crops were destroyed with an estimated economic loss of 8.68 million US\$ as shown in Figure 9. It was further indicated that $\sim 1499.9$ ha of rice standing crop was submerged, which resulted in an estimated economic loss of 2.9 million US\$. Likewise, sugarcane standing crop on $\sim 1029.1$ ha was destroyed, which incurred an estimated economic loss of 2.9 million US\$. A total of 479.1 ha of cotton crop was completely destroyed, with an estimated economic loss of 1.1 million US\$. Similarly, about 1174.7 ha of fodder crops were inundated with an estimated economic loss of 1.8 million US\$ (Fig. 9).

According to community perception, an average estimated economic cost of rice crop on per ha was 1934 US\$, sugar cane was 2906 US\$, cotton was 2325 US\$, fodder crop was 1611 US\$.

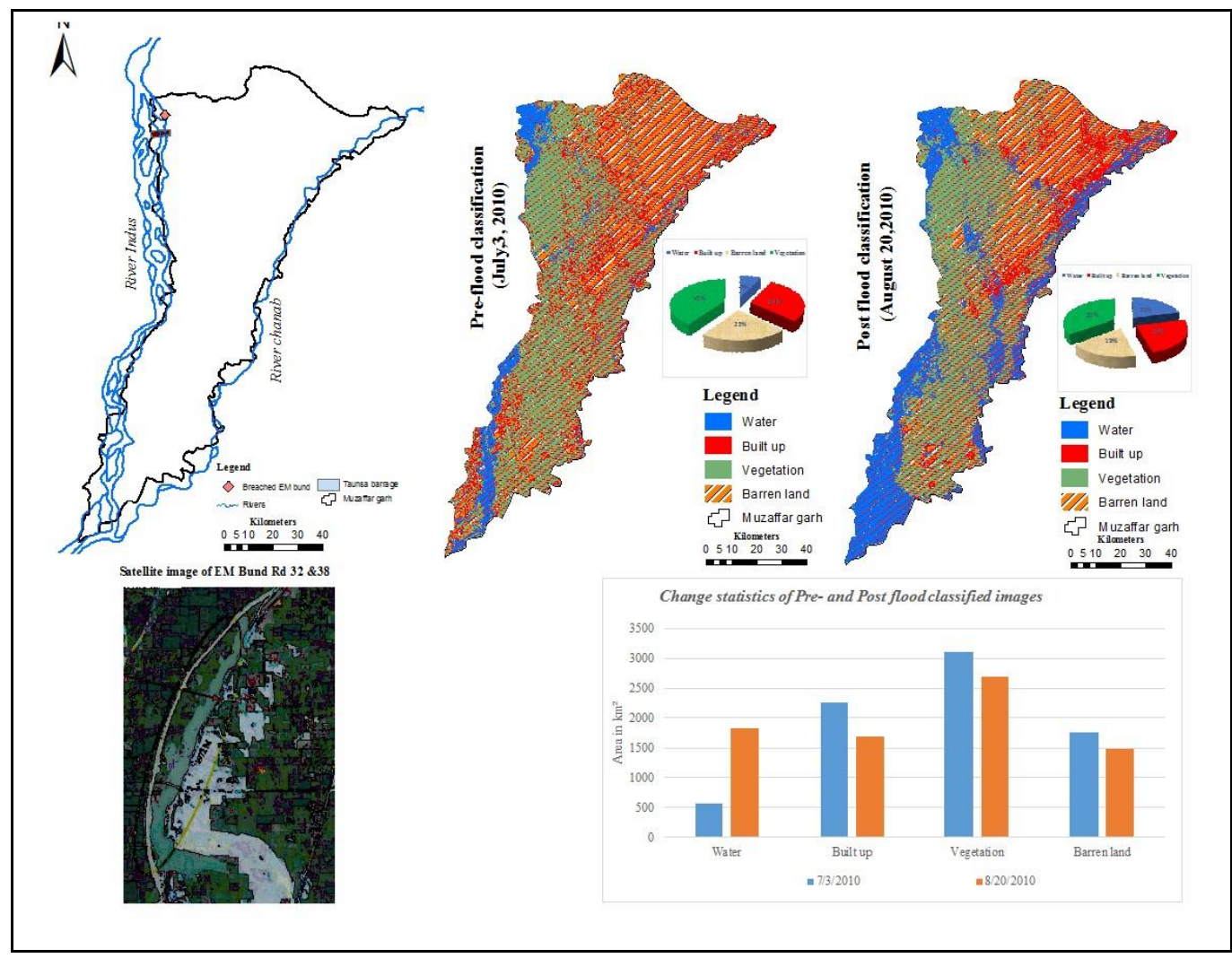

Figure 7. Pre and post flood change detection statistics and classification

\section{Damage to livestock}

Muzaffar garh is ranked as the 2nd largest district in livestock sector in Punjab province, Pakistan (GoP, 2017). People usually keep subsistence and commercial livestock for their source of earning, which include buffaloes, cows, sheep, goats, oxen, donkeys and camels in the study area. As Figure 10 shows that a total number of 1172 livestock animals were found dead with an estimated economic loss of 0.761 million US\$. The loss of buffaloes has incurred an estimated economic cost of 0.404 million US\$ while an estimated economic cost by loss of cows was 0.28 million US\$. Whereas 
the loss of goats, sheep and donkeys has imposed a collective estimated economic loss of 0.077 million US\$ (Fig. 10). The survey indicated that the maximum loss of animals was reported from the Kot addu surveyed area, where the flood depth was maximum revealed by the flood depth spatial analysis as shown in Figure 8. During field survey, the average estimated economic cost was determined as per community estimate, the average economic estimated cost of buffalo was 1176 US\$, of cow was 823 US\$, of goat and sheep was 176.4 US\$ and of donkey was 94 US\$ per community each.

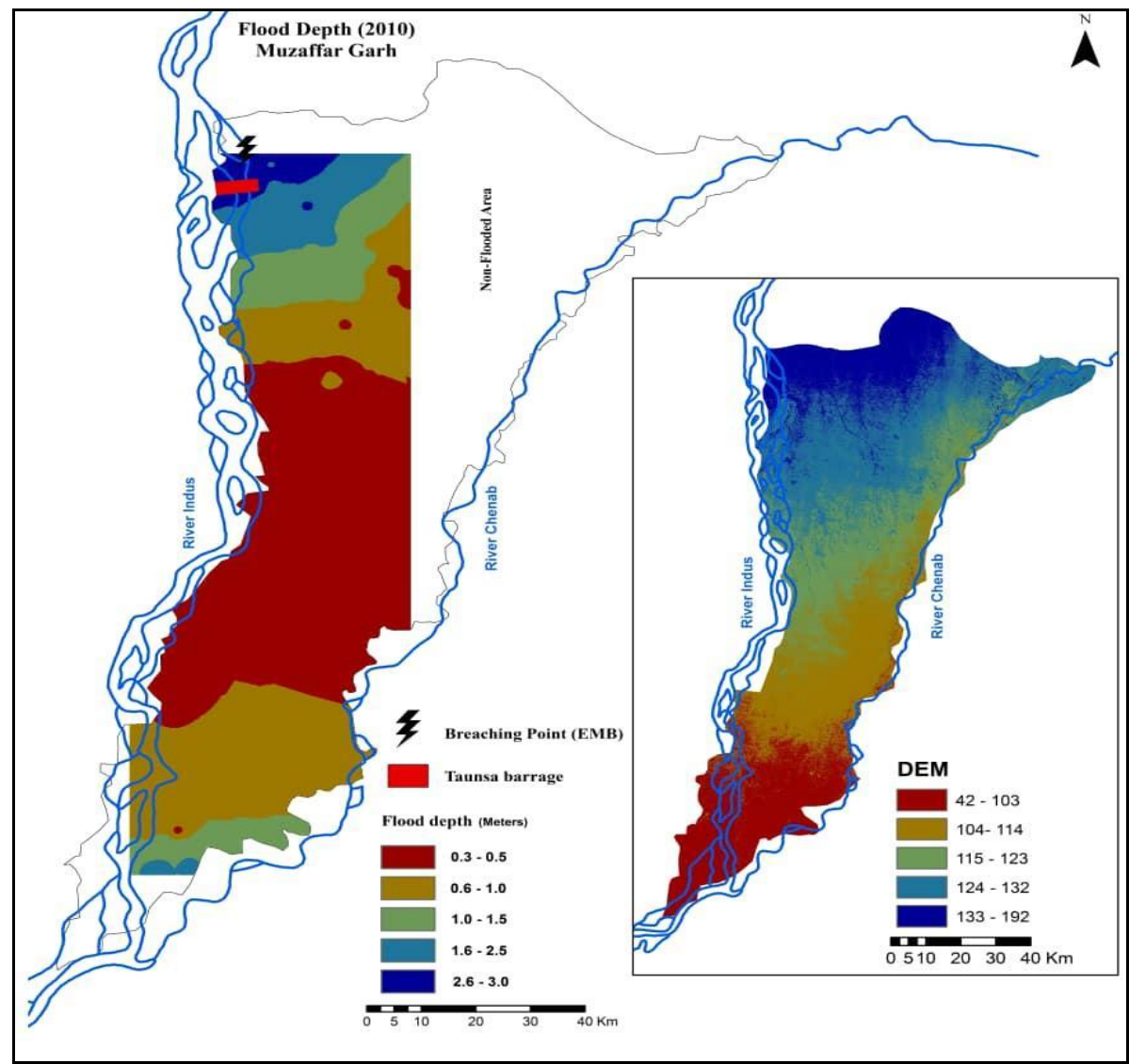

Figure 8. Spatial pattern of flood depth and Digital Elevation Model (DEM) of Muzaffar garh

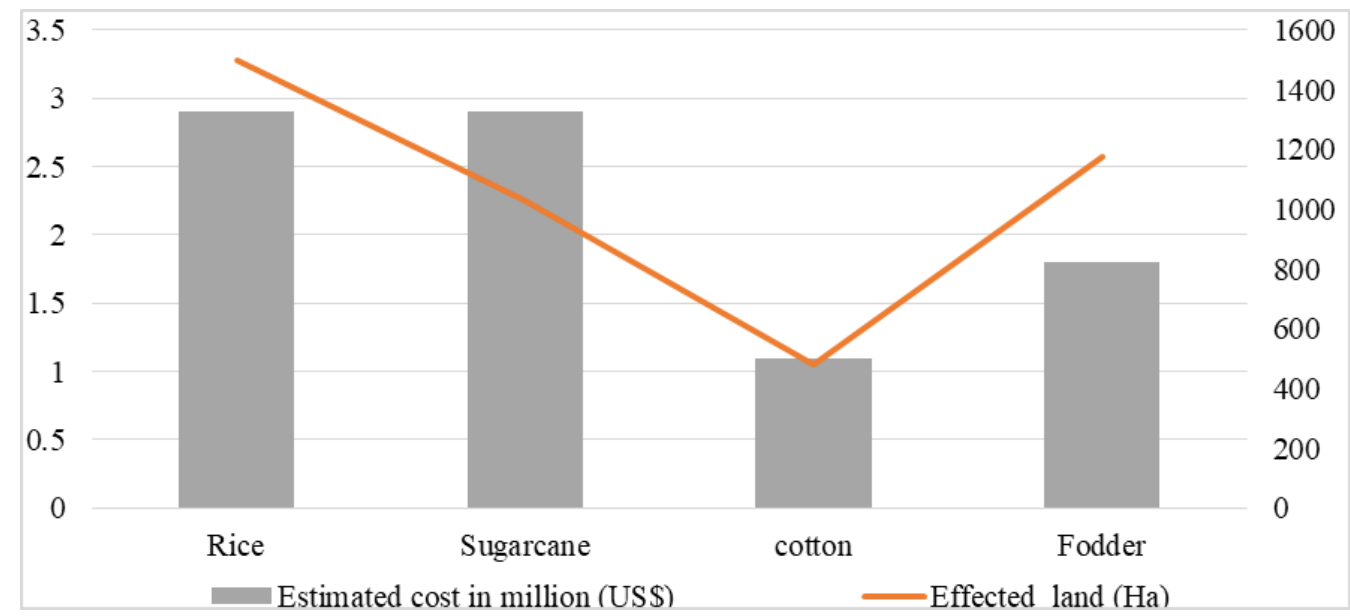

Figure 9. Damaged agriculture crops and estimated loss in million (US\$) 


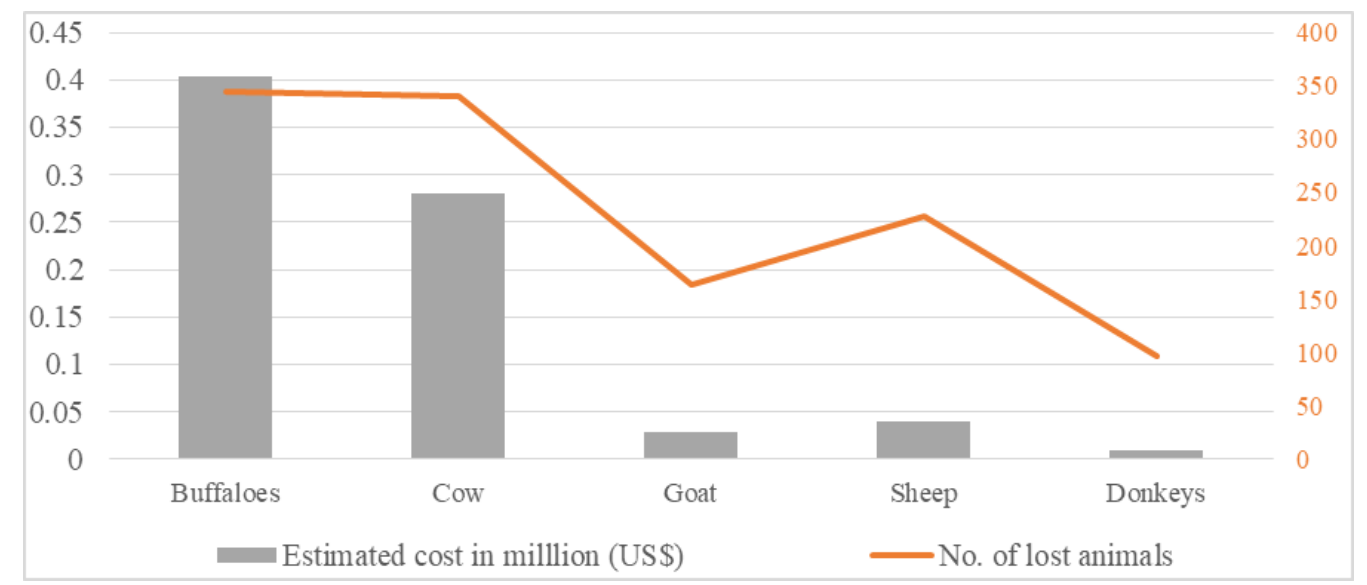

Figure 10. Number of lost livestocks estimated loss in million US\$

\section{Damages to houses}

In the study area, housing structures were very dissimilar with respect to urban and rural areas. Brick houses and mud houses were found in the study area. Field observation and result revealed that the brick houses have more coping capacity in term of flood resilience and structural vulnerability, whereas mud houses have no such flood resilient coping capacity and have high vulnerability to flooding. As Table 2 shows a total of 2673 houses were located in the study area with 1859 mud houses and 814 brick houses. A total of 776 mud houses were partially damaged with an estimated economic loss of 0.27 million US\$, and about 768 mud houses were completely damaged with an estimated economic loss of 0.54 million US\$ (Table 3). As a result, about $83 \%$ mud houses were found partially and completely damaged in the study area. In addition to this, a total of 360 brick houses were found partially damaged with an estimated economic loss of 0.25 million US\$. Besides that, 188 brick houses were found fully damaged with an estimated economic loss of 0.26 million US\$. The community estimated that the average cost per partially and fully damaged mud house was 353 US\$ and 706 US\$, respectively. Similarly, they had also indicated that the average rehabilitation cost of partially and fully damaged brick house were 706 US\$ and 1412 US\$, respectively (Table 4).

\section{Damages to infrastructure}

Road infrastructure is the main source of transportation link between the study area and the rest of the provinces of Pakistan, which in turn stimulate economic growth. In the flood 2010, major G.T. Roads and intra-district roads were severely damaged. According to Communication and Works Department (C\&W) Punjab, a total of $150 \mathrm{~km}$ road network was fully damaged with an estimated economic loss of 3 million US\$. For example, the road that connects G.T. Road in Taunsa Sharif to Multan via Muzaffar garh was seriously damaged from various places with the width of around $100 \mathrm{~km}$. Further, Pak-Arab Oil Refinery Company (PARCO), which is located along this road, suspended oil supply in the whole country due to this flooding event. As a result, Kot addu power plant and Lalpir thermal power plant in Muzaffar garh, which depends on the oil supply from PARCO, were partially shut down, which meant that only $1600 \mathrm{MW}$ was generated instead of the maximum capacity of $2400 \mathrm{MW}$. 
Table 2. Damages to mud and brick houses and estimated loss in million US\$

\begin{tabular}{c|c|c|c|c|c}
\hline Sr. no. & $\begin{array}{c}\text { Type of } \\
\text { houses }\end{array}$ & $\begin{array}{c}\text { Total no. of } \\
\text { houses }\end{array}$ & $\begin{array}{c}\text { Partially } \\
\text { damaged }\end{array}$ & $\begin{array}{c}\text { Completely } \\
\text { damaged }\end{array}$ & $\begin{array}{c}\text { Estimated loss in } \\
\text { million US\$ }\end{array}$ \\
\hline 1 & Brick houses & 814 & 360 & 188 & 0.5 \\
2 & Mud houses & 1859 & 776 & 768 & 0.81 \\
\hline
\end{tabular}

Table 3. Study area: damages to mud houses

\begin{tabular}{c|c|c|c|c}
\hline \multirow{2}{*}{ Surveyed areas } & \multicolumn{4}{|c}{ Mud houses } \\
\cline { 2 - 5 } & $\begin{array}{c}\text { Total number of } \\
\text { houses }\end{array}$ & $\begin{array}{c}\text { Partially } \\
\text { damaged }\end{array}$ & $\begin{array}{c}\text { Completely } \\
\text { damaged }\end{array}$ & $\begin{array}{c}\text { Loss in million } \\
\text { US\$ }\end{array}$ \\
\hline Kot addu & 685 & 256 & 308 & 0.30 \\
Ali pur & 594 & 225 & 265 & 0.27 \\
Muzaffar garh & 335 & 180 & 105 & 0.14 \\
Jatoi & 245 & 115 & 90 & 0.10 \\
\hline
\end{tabular}

Table 4. Study area: damages to brick houses

\begin{tabular}{c|c|c|c|c}
\hline \multirow{2}{*}{ Surveyed areas } & \multicolumn{4}{|c}{ Brick houses } \\
\cline { 2 - 5 } & $\begin{array}{c}\text { Total number of } \\
\text { houses }\end{array}$ & $\begin{array}{c}\text { Partially } \\
\text { damaged }\end{array}$ & $\begin{array}{c}\text { Completely } \\
\text { damaged }\end{array}$ & $\begin{array}{c}\text { Loss in million } \\
\text { US\$ }\end{array}$ \\
\hline Kot addu & 274 & 126 & 68 & 0.18 \\
Ali pur & 234 & 109 & 55 & 0.15 \\
Muzaffar garh & 175 & 70 & 35 & 0.09 \\
Jatoi & 131 & 55 & 30 & 0.08 \\
\hline
\end{tabular}

The railway line is the other source of transportation in the study area. According to railway officials, around $4 \mathrm{~km}$ long railway track was burst in various locations. However, the most damaged tracks were in Kot addu due to the gushing water flow from nearby breached EM embankment. The devastated tracks of $1.5 \mathrm{~km}$ occurred in between Kot addu station to Taunsa Barrage station and around $2.5 \mathrm{~km}$ bursted track was reported in between Bud railway station to Memood kot railway station. The total estimated economic loss was 0.1 million US\$.

The analysis revealed that following the collapse of EM embankment, the floodwater roared through Thal Panjnad (T-P) link canal and breached it due to the excessive spillover from the canal capacity. Further this torrent water drained into Muzaffar garh canal, which could not sustain the pressure of a destructive water and resulted in breaching at many points. According to the District Irrigation Department, collectively around $15 \mathrm{~km}$ irrigation channels were damaged by flood-2010 in the study area with a total estimated economic loss of 0.32 million US\$.

In addition to this, flood had also seriously damaged bridges that were constructed over the irrigation channels for communication and transportation purposes. As Table 5 shows a total of 15 bridges were completely damaged with an estimated loss of 0.151 million US\$. Similarly, the flood has also disrupted electric power supply in the study area for almost two months by damaging more than 100 electric power poles and electric supply lines. According to Multan Electric Power Company (MEPCO), a total 
of 0.15 million US\$ economic loss was estimated for rehabilitation to recover the power supply.

The results of this study were supported by recent related research studies. Mahmood et al. (2019) concluded that 2010 flood in the central Indus Basin was devastating in term of agricultural damages and infrastructure. Gaurav et al. (2011) claimed that the Indus flood 2010 was triggered due to engineering structures of barrages and embankments along the Indus Basin. Hashmi et al. (2012) found that flood 2010 in Pakistan was very damaging in terms of infrastructure and agricultural losses. He further explained that the agricultural sector was badly affected by damaging of standing agriculture crops. Mahmood et al. (2016a) concluded that the 2010 flood in Pakistan was destructive in terms of damages to buildings, infrastructure, and huge economic losses to agriculture. Rehman and Khan (2013) found that 2010 flood disaster has triggered huge losses to infrastructure due to damaging of building, roads and canals. He further explained that infrastructure is the most flood affected sector in the upstream areas of the Indus.

Table 5. Damaged bridges and estimated loss in million US\$

\begin{tabular}{c|c|c}
\hline Tehsil & Number of damaged bridges & Estimated loss in million US\$ \\
\hline Kot addu & 10 & 0.071 \\
Ali pur & 2 & 0.011 \\
Muzaffar garh & 2 & 0.011 \\
Jatoi & 1 & 0.058 \\
\hline
\end{tabular}

\section{Discussion}

The flood 2010 occurred in the study area following the worst weather forecast ever recorded in history by Pakistan meteorological stations in the month of July 2010, with respect to cloud formation incorporated with spatial extent and duration of monsoon rainfall, as a result of the convergence of monsoon winds with upper air jet stream over the North-western regions of KPK province, Pakistan (PMD, 2010; Rehman and Khan, 2013; Mahmood et al., 2016a, b). As Figure 4 shows the evidence of high rainfall of more than $250 \mathrm{~mm}$ recorded during 2010 in comparison with last decade rainfall data that triggered the high inflow of $27184 \mathrm{~m}^{3} / \mathrm{s}$ at Taunsa Barrage. This high inflow was somehow equal to the designed capacity of the barrage as shown in Figure 3. Despite that the water flow was crossing at an alarming level, no action was timely taken to decide the breaching section at emergency purpose. In addition to this, as Figure 5 shows that the influence of sub-weir construction and its upstream narrowing embankments certainly decreased the designed carrying capacity of the Taunsa Barrage. Furthermore, the Indus is famous for carrying a high sediment load from the Himalayas foothills and Taunsa Barrage structure has stuck huge sediments within the river belt thus causing the river bed raise in the last few years. Moreover, in the years 2004-2008, with the request of the Government of Pakistan (GOP), the World Bank took initiative and provided 144 Million US\$ for the remodelling of a diversion structure at Taunsa Barrage (Chaudary and Sarwar, 2014). They did the remodelling of the structure in such a way that they had constructed a sub-weir of about $2.5 \mathrm{~m}$ vertical and $274 \mathrm{~m}$ horizontal length downstream of the Taunsa Barrage, as shown in Figure 5. The coffer dam material was used for construction work. The coffer dam discarded material remained at 
the top of sub-weir resulted in a minor blockage and an increased sediment in the river bed eventually resulted in the breach of the EM embankment.

The findings regarding flood management at Taunsa Barrage revealed that there was no breaching outlet upstream on either side of the barrage. But in fact, the natural topographical slope and depression in the west side upstream, that can divert the emergency water to the depression areas is missing. As such, once flood peak wave passed to downstream, the emergency water can recede back to the river bed. Furthermore, the west bank is scarcely populated in terms of settlements, and economic developments. This resulted in less loss of life and properties since there was no such defined breaching outlet on the western side. In comparison with recent breached east embankment, there were dense human settlements with intensive agriculture crop cultivations and strong infrastructural developments (Fig. 6). The worst in fact is that the flood 2010 overbank water did not return to the river. Rather it was rushed and remained in the cities, towns and agriculture lands for about two months. Further, refilling process took 10 days, overbank bursted water remained destructive in nature with high intensity and destroyed everything that came in its way. Similarly, technical negligence and mismanagement of the Taunsa Barrage was also revealed. The heavy, prolonged rainfall in upstream of the Indus was forecasted by PMD, but there were no pre-flood measures taken to manage or even to reduce the impacts of flood by rapid structural maintenance of the embankments. In addition to this, they were also failed to operate the newly motorized hoisting system, as a result ten barrage gates were not totally opened (Chaudary and Sarwar, 2014, 2016). This led to the sudden pressure at the barrage and caused the collapse of EM embankment at Rd 32-38. Similarly, the Kosi flood 2008, in the eastern part of India also occurred due to a $1.2 \mathrm{~km}$ long breach in the eastern embankment at Kusaha, which was located almost $12 \mathrm{~km}$ upstream of the Kosi Barrage. Likewise, Indus, the Kosi River carries a very high sediment influx from upstream areas which caused the river bed level raise and a super elevated flowing in condition toward lower reaches in the Kusaha region. Further, negligence and improper maintenance of the embankments were also found which made this Kosi river more disastrous for the affected population in the Kusaha region (Sinha, 2010). In contrast, the Kosi flood disaster 2008 in India occurred due to a breach at eastern embankment with a very low discharge of $4078 \mathrm{~m}^{3} / \mathrm{s}$, whereas in southern Punjab 2010 flood occurred due to the breach of the EM embankment at Rd 32-38 near Taunsa Barrage with the discharge of $27184 \mathrm{~m}^{3} / \mathrm{s}$.

Depth of the flood 2010 in the study area was unevenly located in all surveyed areas with the help of GPS and measuring tape. The result shows the correlation between the flood depth and the nature of damages, which increased the flood magnitude of socioeconomic infrastructure damages. During survey, we noticed that a total of $75 \%$ of the households indicated that flood depth varied from 1 to $2 \mathrm{~m}$ while the remaining $25 \%$ households indicated that flood depth varied from 2.1 to $3 \mathrm{~m}$ (Fig. 8). In addition, flood duration varied due to the slight geographical and topographical variability in the area and soil texture. The most consistent observation was that almost all the respondents indicated that flood water remained stagnant from 2 to 3 months in post flood situation. This increased the magnitude of damages as the mud houses and crop were subjected to adverse conditions.

Supervised classification was used for analyzing the landuse/cover change in the study area. Supervised classification result shows that built up areas has been decreased by $8.02 \%$ in post-flood situation. Further survey indicated that most of the respondents 
belonged to very poor families and settled in mud houses. Flood had badly destroyed and even washed them away. Similarly, infrastructure and other built up areas were also destroyed in such a way that their materials were dispersed. In some areas, flooded water transported households' material in a different way, such as traction by rolling and suspension. Thus, survey evidences were found consistent with supervised classification result as decrease in built up area was shown in post flood classification (Fig. 7). Moreover, vegetation area had decreased by $5 \%$ in post flood classification and flood 2010 occurred in the month of July and August during the growing season of Kharif crops including rice, sugarcane, cotton and maize with other fodder crops. Thus, the visible green due to increase in chlorophyll was found in both pre and post flood instances and resulted in vegetation areas having the highest values in comparison with all other classes. Similarly, slight difference found in barren class during pre and postflood classification (Fig. 7). Further, most of the barren land lies in the northern and north-eastern part of the study area characterized by high elevation and far away from the proximity of river which makes it the proposed area for safe evacuation places if flood occurs in future flood risk reduction.

We noticed that more damage and destruction was found in the agricultural sector in comparison with other sectors. Flood was not only very destructive in terms of agriculture standing crops damages, but also destroyed the district government wheat seed stocks. Further, disruption was observed in the forthcoming Rabi season crops, which were cultivated very late due to the presence of flood water for almost 8 weeks. Additionally, most of the damages to agriculture standing crops were found in Kot addu area as it was located very near to the breached EM embankment. Similarly, it was indicated that the maximum livestock damages were also reported from Kot addu, as this area had faced roaring disastrous unpredictable flood water with long duration and maximum depth.

Observations also revealed that an increase in duration and depth of flood is proportional to the increase of sensitivity of livestock. The depth difference influenced the loss numbers of different animals. For example, in areas with high flood depth of above $1.5 \mathrm{~m}$ experienced more buffaloes, cows, and donkeys were lost while areas having less than 1.5 $m$ depth experienced the maximum losses of sheep and goat according to the records.

As far as housing structure is concerned, there were two types of houses that were found in the area namely, brick houses and mud houses. The brick houses were more resilient against flood vulnerability, whereas mud house had very little resilient capacity and had high flood vulnerability. In addition to this, a total of 1544 of mud houses were found completely and partially destroyed. We noticed that about $50 \%$ of the people have monthly income of less than 130 US\$, which limited their capability to build brick houses. That is why, a large number of registered damaged houses were mud houses and mostly reported from the Kot addu survey area. Further, it is highly recommended that there is a need of appropriate financial aid to the vulnerable people to construct their flood resilient houses that can withstand future flooding events.

\section{Conclusion}

District Muzaffar garh is one of the unprivileged districts of South Punjab, Pakistan. It is located in a near juxtaposition to the river Indus and Chenab from its both sides which are exposing it to riverine flooding. Almost every year, riverine flooding occurs in the study area from the east bank of the mighty River Indus and the west bank of the River Chenab. In 2010, the worst riverine flooding of the century occurred in the study 
area due to 4-days extra-ordinary amount of monsoon rainfall in the upstream of the Indus Basin that triggered a discharge of about $28317 \mathrm{~m}^{3} / \mathrm{s}$ at Taunsa Barrage, which exceeded its capacity. The East Marginal (EM) embankment could not sustain the discharged water and it eventually collapsed. The collapse of the Taunsa Barrage caused inundation in the study area and consequently, agricultural standing crops, livestocks, infrastructure, human settlements were destroyed or damaged. This also led to a temporary shift for most of the local people to safe locations.

The leading majority of above $40 \%$ surveyed households were engaged directly and indirectly since the agricultural sector is considered as one of the main sources of earnings. Throughout the study area, flood has badly affected the standing crops of Kharif season with an estimated economic loss was 8.68 million US\$ and it is largely one of the most exposed economic sectors to recurrent floods and poor mitigation approaches. Overall, total damages from flood 2010 were about 14.23 million US\$. Agriculture and Infrastructure were seriously damaged sectors with an estimated economic losses of 8.68 and 3.48 million US\$, respectively. Similarly, the economic damages to housing and livestock sectors were 1.31 and 0.761 million US\$. Furthermore, most of the surveyed respondents earned less than 130US\$, which is not permitting them to build resilient brick houses. Therefore, the majority of them have been living in mud houses, which are highly vulnerable to floods. This circumstance had further intensified and exposed the physical and economic vulnerabilities of local communities to riverine floods. Out of all surveyed areas, the maximum damages to all economic sectors were reported from Kot addu which lies in the proximity of the breached EM embankment. Furthermore, most of the respondents were living in flood plain areas and that has further increased the intensity of massive flooding and imposed the huge economic losses to this vicinity.

The study concludes that, as many previous related studies and forums cited in the year of 2010, high rainfall in upstream Indus was the main cause of flooding in the entire Indus Basin. In comparison to this study, it is defined that the resulting discharge $\left(27184 \mathrm{~m}^{3} / \mathrm{s}\right)$ at Taunsa Barrage did not exceed its proposed designed capacity $\left(28317 \mathrm{~m}^{3} / \mathrm{s}\right)$. However, the obstacle of excessive volumes of water together with a large quantity of sediment deposition in the head up because of structural sub-weir construction in downstream and narrow river bed due to the construction of protective embankments in the upstream, has reduced the designed carrying capacity of the Taunsa Barrage. Moreover, the concerned authority and river management department did not take any measures corresponding to upraise the protective embankments with respect to flood management in 2010. This research study provides effective mixed method approaches to the local, regional and national disaster management authorities for devising the effective flood management plan with the identification of breaching points in any emergency situation to minimize future flood risk, human causalities and socio-economic damages. Moreover, this study will bring the attention of disaster management authorities to divert their obsolete strategy of river control to river management.

It can finally be concluded that this increase of population sprawl in floodplain for socio-economic development is expected to continue in the future in the study region. Similarly, there is an utmost need of effective flood-risk zonation and strategies to reduce the future impacts of riverine flood disasters in the study area. There is a need of effective studies on the human interventions in the river basins in term of cost-benefit approach, including impacts on human and environment. In addition to this, zonespecific flood-risk reduction strategies should be the next step. 
Acknowledgements. This work was funded by the National Key Research and Development Program (2018YFC1506506), the Frontier Project of Applied Foundation of Wuhan (2019020701011502), the Natural Science Foundation of Hubei Province (2019CFB736), the Fundamental Research Funds for the Central Universities (2042018kf0220) and the LIESMARS Special Research Funding.

\section{REFERENCES}

[1] Ali, A. (2013): Indus Basin Floods: Mechanisms, Impacts, and Management. - Asian Development Bank, Mandaluyong City, Philippines.

[2] Alphan, H., Doygun, H., Unlukaplan, Y. I. (2009): Post-classification comparison of land cover using multitemporal Landsat and ASTER imagery: the case of Kahramanmaras, Turkey. - Environ Monit Assess 151: 327-336.

[3] Banerjee, L. (2010): Effects of flood on agricultural productivity in Bangladesh. - Oxford Development Studies 38: 339-356.

[4] Cann, K. F., Thomas, D. R., Salmon, R. L., Wyn-Jones, A. P., Kay, D. (2013): Extreme water-related weather events and waterborne disease. - Epidemiology and Infection 141: 671-686.

[5] Chaudary, Z. A., Sarwar, M. K. (2014): Rehabilitated Taunsa Barrage: prospects and concerns. - Science, Technology and Development 33(3): 127-131.

[6] Chaudary, Z. A., Sarwar, M. K. (2016): Catastrophe of flood 2010 at Taunsa Barrage; review of technical findings of Punjab Judicial Tribunal Report. - Science, Technology and Development 35(1): 1-5. DOI: 10.3923/std.2016.1.5.

[7] Chohan, K., Ahmad, S. R., Islam, Z., Adrees, M. (2015): Riverine flood damage assessment of cultivated lands along Chenab River using GIS and remotely sensed data: a case study of district Hafizabad, Punjab, Pakistan. - J Geogr Inf Syst 7: 506-526.

[8] Dawood, M., Mahmood, S., Rahman, G., Rahman, A. (2017): Impact of rain-fall fluctuation on river discharge in Hindu Kush Region, Pakistan. - Abasyn J Soc Sci 10: 246-259.

[9] El Bastawesy, M., Gabr, S., Mohamed, I. (2015): Assessment of hydrological changes in the Nile River due to the construction of Renaissance Dam in Ethiopia. - Egypt. J. Remote Sens. Space Sci. 18(1): 65-75.

[10] Federal Flood Commission (FFC) (2010): Annual Flood Report. - Ministry of Water and Power, Government of Pakistan, Islamabad.

[11] Gaurav, K., Sindha, R., Panda, P. K. (2011): The Indus flood of 2010 in Pakistan: a perspective analysis using remote sensing data. - Nat. Hazards 59: 18151826.http://dx.doi.org/10.1007/s11069-011/9569-6.

[12] Geis, D., Steeves, B. (1998): Flood Hazards. - Association of Collegiate Schools of Architecture, Inc. https://www.jstor.org/stable/1424687.

[13] Ghosh, D. D., Mandal, M., Banerjee, M. (2015): Environmental impact of embankment breaching: a case study along lower reaches of Ajay River, West Bengal, India. International Journal of Arts, Humanities and Management Studies 01: 09.

[14] Government of Pakistan (1999, 2017): District Census and disaster Report of Muzaffar Garh. - Population Census Organization, Islamabad.

[15] Haq, M., Akhtar, M., Muhammad, S., Paras, S., Rahmatullah, J. (2012): Techniques of remote sensing and GIS for flood monitoring and damage assessment: a case study of Sindh province, Pakistan. - Egyptian Journal of Remote Sensing and Space Sciences 15: 135-141.

[16] Hashmi, H. N., Siddiqui, Q. T. M., Ghuman, A. R., Kamal, M. A., Mughal, H. A. (2012): critical analysis of 2010 floods in Pakistan. - African Journal of Agricultural Research 7: 1054-1067.

[17] Howe, J., White, I. (2002): The Geography of the autumn 2000 floods in England and Wales: causes and solution. - Geographical Association 87: 116-124. 
[18] Khalid, B., Cholaw, B., Alvim, D. S. (2018): Riverine flood assessment in Jhang district in connection with ENSO and summer monsoon rainfall over Upper Indus Basin for 2010. - Nat Hazards 92: 971. DOI: https://doi.org/10.1007/s11069-018-3234-y.

[19] Khan, A. N. (2005): An assessment of floods hazard causes for efficient flood plain management: a case of Neelam-Jehlum Valley. - Pakistan Geographical Review 60(1): 42-53.

[20] Khan, B., Iqbal, M. J., Yosufzal, M. A. K. (2009): Flood risk assessment of river Indus of Pakistan. - Arab J Geosci 4: 115-122.

[21] Laghari, A. N., Vanham, D., Rauch, W. (2012): The Indus basin in the framework of current and future water resources management. - Hydrol. Earth Syst. Sci 16: 1063-1083.

[22] Mahmood, S., Rani, R. (2018): Extent of 2014 Flood Damages in Chenab Basin Upper Indus Plain. - In: Antunes Do Carmo, J. S. (ed.) Natural Hazards-Risk Assessment and Vulnerability Reduction. IntechOpen, London. https://doi.org/10.5772/intec hopen.79687.

[23] Mahmood, S., Khan, A. H., Mayo, S. M. (2016a): Exploring underlying causes and assessing damages of 2010 flash flood in the upper zone of Panjkora River, Pakistan. Nat Hazards 83(2): 1213-1227.

[24] Mahmood, S., Khan, A. H., Ullah, S. (2016b): Assessment of 2010 flash flood causes and associated damages in Dir Valley, Khyber Pakhtunkhwa Pakistan. - Int J Disaster Risk Reduct 16: 215-223.

[25] Mahmood, S., Rahman, A., Sajjad, A. (2019): Assessment of 2010 flood disaster causes and damages in district Muzaffargarh, Central Indus Basin, Pakistan. - Environmental Earth Sciences 78: 63.

[26] Melgani, F., Bruzzone, L. (2004): Classification of hyper spectral remote sensing images with support vector machine. - IEEE Trans. Geosci. Remote Sens. 42(8): 1778-1790.

[27] Messner, F., Penning, R. E., Green, C., Meyer, V., Tunstall, S., Veen, A. (2007): Evaluating flood damages: guidance and recommendations on principles and methods. Flood Site Project Deliverable. Report no. T09-06-01.

[28] Milly, P. C. D., Wetherald, R. T., Dunne, K. A., Delworth, T. L. (2002): Increasing risk of great floods in a changing climate. - Nature 415: 514-517.

[29] Natalia, K., Shelestov, A., Skakun, S., Kravchenko, O. (2008): Data assimilation technique for flood monitoring and prediction. - International Journal Information Theories \& Applications 15: 76-83.

[30] National Disaster Management Authority (NDMA) (2010): annual flood report 2010. Government of Pakistan, Islamabad.

[31] Pakistan Metrological Department (PMD) (2010): Annual flood report 2010. Government of Pakistan, Islamabad.

[32] Punjab Provincial Disaster Management Authority (PPDMA) (2010): Annual Flood Report 2010. - Government of Punjab, Lahore.

[33] Rahman, A., Khan, A. N. (2011): Analysis of flood causes and associated socio-economic damages in the Hindu Kush region. - Nat Hazards 59: 1239-1260. http://dx.doi.org/10.1007/s11069-0011-9830-8.

[34] Rahman, A., Khan, A. N. (2013): Analysis of 2010-flood causes, nature and magnitude in the Khyber Pakhtunkhwa, Pakistan. - Nat Hazards 66: 887-904.

[35] Sinha, R. (2010): A river runs through it. - Public Serv Rev Int Dev 17: 20-22.

[36] Shah, S. M. S., Gabriel, H. F. (2002): Floods in Pakistan. - A Country Paper presented in the Regional Media and Policy Workshop on "Fencing Floods in South Asia: Disaster Preparedness Through Risk Communication". Dec. 15-18, 2002, Islamabad, Pakistan.

[37] Solheim, I., Solbo, S., Indregard, M., Lauknes, I.(2001): User requirements and SARsolutions for flood mapping. $-4^{\text {th }}$ International Symposium on Retrieval of Bio- and Geophysical Parameters from SAR Data for Land Applications, Innsbruck, Austria.

[38] Syvitski, J. P., Brakenridge, G. R. (2013): Causation and avoidance of catastrophic flooding along the Indus River, Pakistan. - GSA Today 23(1): 4-10. 
[39] Tariq, M. A. U. R., Giesen, V. D. N. (2012): Floods and flood management in Pakistan. Phys. Chem. Earth 47: 11-20. http://dx.doi.org/10.1016/j.pce.2011.08.014.

[40] Walder, J. S., o'connor, J. E. (1997): Methods for predicting peak discharge of floods caused by failure of natural and constructed earthen dams. - Water Resources Research 33: 2337-2348.

[41] Zhou, C., Yang, C. J., Baoiln, L. I., Wang, S. (2000): Flood monitoring using multitemporal AVHRR and RADARSAT imagery. - Photogramm. Eng. Remote. Sens. 66: 633-638. 